\title{
Physical activity levels and energy expenditure of 9-year-old - 12-year-old overweight and obese children
}

\author{
Authors: \\ Chanelle Kemp ${ }^{1}$ \\ Anita Elizabeth Pienaar ${ }^{1}$ \\ Affiliations: \\ ${ }^{1}$ School of Biokinetics, \\ Recreation and Sport \\ Science, North-West \\ University, Potchefstroom \\ Campus, South Africa \\ Correspondence to: \\ Chanelle Kemp \\ Email: \\ chanelle.kemp@nwu.ac.za \\ Postal address: \\ Private Bag X6001, \\ Potchefstroom 2520, \\ South Africa \\ Dates: \\ Received: 08 Apr. 2010 \\ Accepted: 23 Sept. 2010 \\ Published: 07 Mar. 2011 \\ How to cite this article: \\ Kemp, C. \& Pienaar, \\ A.E., 2011, 'Physical \\ activity levels and energy \\ expenditure of 9-year-old \\ -12-year-old overweight \\ and obese children', Health \\ SA Gesondheid 16(1), Art. \\ \#557, 6 pages. doi:10.4102/ \\ hsag.v16i1.557
}

(C) 2011. The Authors. Licensee: OpenJournals Publishing. This work is licensed under the Creative Commons Attribution License.
The high occurrence of overweight and obesity amongst children is a disturbing health problem worldwide. Possible causes of increasing childhood obesity are inactivity and energy imbalances. The aim of this study was to analyse the total energy expenditure (TEE) and physical activity levels in 9-year-old - 12-year-old overweight and obese children during a weekday and a weekend day, as well as during a weekday morning and afternoon. Twenty-four 9-year-old - 12-year-old children (seven boys and 17 girls), of whom nine were overweight and 15 were obese, were selected from seven public primary schools for this study. Body mass index (BMI) cut-off points were used to distinguish between overweight and obese. Each participant wore an ACTICAL ${ }^{\mathrm{TM}}$ monitor to determine their physical activity levels and TEE. It was found that the TEE of the children did not differ between a week day and a weekend day, although the TEE of the week day afternoon differed significantly from that of the weekday morning. Unlike the overweight children, none of the obese children met the requirements of 60 minutes of moderate-intensity physical activity per day. Strategies should be found to increase the activity levels of overweight and, especially, obese children, specifically during the mornings and over weekends.

Die hoë voorkoms van oorgewig en obesiteit onder kinders is wêreldwyd 'n kommerwekkende gesondheidsprobleem. Fisieke onaktiwiteit en energiewanbalanse word as moontlike oorsake van die probleem beskou. Die doel van hierdie studie was om die totale energieverbruik (TEV) en fisieke-aktiwiteitsvlakke van 9-jarige - 12-jarige oorgewig- en obese kinders tydens 'n totale weeksdag en naweekdag te ontleed, asook tydens die oggend en middag van ' $n$ weeksdag. Vier-en-twintig 9-jarige - 12-jarige kinders (sewe seuns en 17 dogters), waarvan nege oorgewig en 15 obees was, is uit sewe publieke laerskole vir die studie gekies. Afsnypunte volgens die liggaamsmassa-indeks (LMI) is gebruik om tussen oorgewig en obees te onderskei. Elke deelnemer het ' $n$ ACTICAL ${ }^{\mathrm{TM}}$ monitor gedra om hul fisieke-aktiwiteitsvlakke en TEV te bepaal. Die studie het getoon dat die TEV van die kinders op 'n weeksdag en naweekdag nie verskil het nie, alhoewel TEV tydens die middag van die weeksdag betekenisvol verskil het van die oggend s'n. Anders as die oorgewig kinders, het geen van die obese kinders aan die voorgestelde riglyn van 60 minute se matig intensiewe fisieke aktiwiteit per dag voldoen nie. Strategieë moet gevind word om die vlakke van aktiwiteit van oorgewig en veral obese kinders te verhoog, spesifiek gedurende die oggende en oor naweke.

\section{Introduction}

The World Health Organization (WHO) defines overweight and obesity as an abnormal or excessive accumulation of fat that can have a negative effect on health (WHO 2009). A body mass index (BMI) (body mass divided by body height squared) of between 25.0 and 29.9 is defined as overweight, while a value higher than 30 denotes obesity. The prevalence of overweight and obesity is increasing dramatically amongst children worldwide (Ogden et al. 2006:1549). The global prevalence of childhood overweight in 2010 was estimated at 38\% in the European region and $46 \%$ in the US (Wang \& Lobstein 2006:11). Research by Armstrong et al. (2006:52) indicated high levels of overweight and obesity amongst South African children, with $14 \%$ and $3.2 \%$ of boys between the ages of 6 years and 13 years presenting as overweight and obese resectively, while the occurrence was $17.9 \%$ and $4.9 \%$ respectively in girls.

Steinbeck (2001:S29) indicates the imbalance between energy intake (food) and energy expenditure (physical activity) as the main reason for excessive fat storage. Physical activity is an underlying component of energy expenditure and modern-day inactive lifestyles contribute to a positive energy balance (more energy is taken in from food than is expended during metabolism) and early development of obesity, as well as a lowered motivation to participate in organised sport (Reilly \& Dorosty 1999:1874; Al-Nakeeb et al. 2007:1). In this regard, Trost et al. (2003:834) maintain 
that a large percentage of primary school children exhibit an elevated risk for a further increase in adiposity owing to poor physical activity levels. According to the President's Council on Physical Fitness and Sports (PCPFS 2008) children and teenagers require 60 minutes' physical activity of moderate intensity per day in order to derive health benefits. This period does not have to include 60 consecutive minutes; bouts of 10 minutes -15 minutes during the course of the day are also considered to be beneficial for their health (PCPFS 2008). Aires et al. (2007:871) report that structured physical activity contributes not only to increasing moderate to high physical activity (MHPA) levels, but also to combating the low levels of MHPA that occur during the days that children do not participate in physical activity.

Unlike younger children who participate significantly more in high levels of moderate intensity physical activity on weekends, adolescents report significantly lower levels of moderate intensity activity over weekends compared to weekdays. A study by Rowlands, Pilgrim and Eston (2007:317) showed that children in England participated in more regular, longer and more intensive physical activity sessions during the week than over weekends. As an indicator of physical activity, Duncan et al. (2007:416) measured participants' daily number of steps on weekdays and weekends. Results showed a higher level of physical activity during the week. In contrast, Grund et al. (2000:299) measured the total energy expenditure (TEE) of six prepubescent children and found that the TEE was higher over the weekend than during the week. Trost et al. (2000:426) also found that participation in moderately intensive physical activity was higher over the weekend in relation to that during the week. From these findings it appears that there is still debate among researchers concerning when the most physical activity takes place. None of the mentioned studies, however, measured the physical activity levels of overweight or obese children. In addition, only a few studies (Vasquez et al. 2006:1115; Aires et al. 2007:871; Goldfield et al. 2008:592) studied the energy expenditure and physical activity levels of overweight or obese children.

Vasquez et al. (2006:1115) studied activity levels of 3-5-yearold obese children, showing that $58 \%$ of their time (488 min.) was spent on low-intensity activities and $4 \%$ (32 min.) on moderately intensive activities during the week, compared to $52 \%$ (405 $\mathrm{min}$.) and $3 \%$ (22 $\mathrm{min}$.) respectively during the weekends. The obese children also used more energy during weekday mornings at their day care centres $(62 \%)$ compared to the amount spent at home (54\%) during the afternoons. Significant differences were also found in the TEE and the predetermined energy requirements for boys and girls. Energy input for children who were obese according to the National Center for Health and Statistics standard (WHO 1986) was already $5.4 \%$ higher in this study than the energy requirements (Vasquez et al. 2006:1115). In a study on 8-yearold - 16-year-old overweight and obese children Aires et al. (2007:871) reported less activity over the weekend compared to that during the week, while similar findings were reported by Trost, McIver and Pate (2005:S531). No studies on physical activity levels or of possible differences between 9-year-old 12-year-old South African overweight or obese girls and boys could be found.

\section{Objectives of the study}

The aim of this study was, firstly, to determine whether 9-year-old-12-year-old overweight or obese children meet the recommended requirements for participation in 60 minutes of moderate intensity physical activity per day. Secondly, the study aimed to determine whether the physical activity levels and energy expenditure of 9-year-old - 12-year-old overweight or obese children during the week differ from that during weekends, and between weekday mornings and afternoons.

\section{Research method and design}

The researchers made use of a convenience sample and a cross-sectional descriptive study design was applied in the study.

\section{Population and sampling}

The research group was recruited from a baseline study on the incidence of overweight and obesity amongst school children in Grades 4-6, which consisted of all Grade 4, 5 and 6 learners (128 boys and 152 girls, $n=280$ ) from two public primary schools in Potchefstroom, South Africa. The headmasters of the schools indicated that their schools represented a good distribution of socio-economic status, race and gender. All the children who were categorised as overweight or obese according to age-specific BMI cut-off points during this baseline study (Cole et al. 2000), were recruited for a follow-up intervention study, of which this study formed part. However, only 20 participants consented. Parents of obese children are usually not eager for their children to participate in studies of this nature, because of the fear for stigmatisation. Practical considerations, such as transportation problems, also contributed to the small sample size. Because the researchers attempted to enlist at least 30 participants for the study, notices were also distributed to the five other public primary schools in Potchefstroom to invite parents to enrol their children for participation. Another four participants were recruited in this manner. The final group ( $n=24$ ) consisted of seven boys (of whom four were overweight and three obese) and 17 girls (of whom five were overweight and 12 obese).

\section{Measuring instruments}

Anthropometry: The standard procedures of the International Society for the Advancement of Kinanthropometry (ISAK) (Marfell-Jones et al. 2006) were used to measure the stature $(\mathrm{m})$, body mass $(\mathrm{kg})$ and the triceps and calf skinfolds $(\mathrm{mm})$ of the participants. BMI and body fat percentage were determined from these measurements by trained level II kinanthropometrists. Participants' fat percentage was calculated according to the following equations: 
fat percentage $=0.610\left(\sum 2 \mathrm{VV}\right)+5.1($ girls $)$

[Eqn 1]

fat percentage $=0.735\left(\sum 2 \mathrm{VV}\right)+1.0$ (boys),

[Eqn 2]

with

$\sum 2 \mathrm{VV}=$ triceps skinfold + calf skinfold.

[Eqn 3]

The BMI of each participant was calculated according to BMI = body mass $/(\text { stature })^{2}$. Because the BMIs of children change with age, an age-specific cut-off point to determine obesity in growing children (Cole et al. 2000:1240) was used to categorise the participants as overweight or obese.

Energy expenditure and physical activity levels: The ACTICAL ${ }^{\mathrm{TM}}$ monitor determines the TEE and the intensity level (sedentary, low, moderate or high) of physical activity (Mini Mitter Company Inc. 2003). According to the manufacturer's instructions and recommendations the monitor has to be held in place on the iliac crest of the left hip by an elastic band with an adjustable clip. The energy component of the ACTICAL ${ }^{\mathrm{TM}}$ software expresses the TEE in metabolic equivalents (METs). The movement (activity count) is converted to units of energy (calories). Specific MET cut-off points describe the intensity level of physical activity. These cut-off points are light $(<2.7)$, moderate $(2.7-4.4)$ and intensive (>4.4) (Mini Mitter Company Inc. 2003). The information obtained from the ACTICAL ${ }^{\mathrm{TM}}$ accelerometers were analysed by means of the ACTICAL ${ }^{\mathrm{TM}}$ software, edition 2.0 (Mini Mitter Company Inc. 2003).

\section{Research procedure}

After planning the study, ethical approval (no. 07M07) was obtained from the North-West University, Potchefstroom Campus. Permission to conduct the study was granted by the Department of Education of the North West Province and the headmasters of the identified schools. Informed consent was obtained from both the parents and the children, and a medical doctor had to declare the children medically fit to participate in the study. Each participant had the opportunity to wear the ACTICAL ${ }^{\mathrm{TM}}$ monitor (a very small, flat device of $2.5 \mathrm{~cm}$ $\mathrm{x} 2.5 \mathrm{~cm}$ ) underneath the clothes for 2 days (1 weekday and 1 weekend day) during the school term before the intervention part of the study commenced. Participants had to wear the ACTICAL ${ }^{\mathrm{TM}}$ for two consecutive days (18 participants on a Friday and a Saturday, and six participants on a Sunday and Monday). The ACTICAL ${ }^{\mathrm{TM}}$ was delivered to each participant and collected again two days later, after which the collected data were captured using the ACTICAL ${ }^{\mathrm{TM}}$ software. The ACTICAL ${ }^{\mathrm{TM}}$ data were collected over a 12-hour period each day (08:00-20:00). Each participant, assisted by their parents, also had to complete an activity diary over the 12hour period in which they had to describe the activities they engaged in. The diary was divided into 30-minute intervals over the entire period. The data for comparison of weekday morning and afternoon activity were divided in two batches spanning 08:00-14:00 and 14:00-20:00 respectively to ensure that the same number of hours was used for analyses of the morning and the afternoon data.

\section{Statistical analysis}

The software package STATISTICA (Statsoft 2009) was used to analyse the data. Means, standard deviations, and maximum and minimum values were used for descriptive purposes. Activity level differences between weekdays and weekend days, as well as for morning and afternoon sessions on the respective days, were evaluated by means of $t$-tests. Statistical significance was defined as $p \leq 0.05$.

\section{Results}

Table 1 provides descriptive statistics of the 24 participants. The group consisted of seven boys (four White, three Black) and 17 girls (10 White, seven Black). The mean age of the group was 11.06 years, with the boys exhibiting a slightly higher mean age (11.36 years) than the girls (10.94 years). More girls than boys were obese $(70.59 \%$ vs $42.86 \%)$, whilst more boys than girls were overweight ( $57.14 \%$ vs $29.41 \%)$. More Black than White girls were obese ( $100 \%$ vs $50 \%)$, whilst more White than Black boys were obese ( $50 \%$ vs $33.34 \%$ ).

The reports mean stature, body mass and BMI for the entire group as well as according to race (Black and White) and gender (boys and girls) is shown in table 2. The boys were slightly taller $(1.52 \mathrm{~m})$ than the girls $(1.51 \mathrm{~m})$, while the girls were heavier $(63.34 \mathrm{~kg})$ than the boys $(60.34 \mathrm{~kg})$. This may explain the higher TEE of the girls. The BMI of the girls was also higher than that of the boys (28.07 vs 26.03$)$.

The weekday and weekend day TEE and physical activity levels of overweight and obese children is described in table 3. The TEE of the group (overweight and obese boys and girls) was higher on the weekend day $(1262.14 \mathrm{kcal})$ than on the weekday $(1181.99 \mathrm{kcal})$, although not significantly. More time was spent in sedentary physical activity (47.47\%) on the weekday than on the weekend day, where most of the time $(54.09 \%)$ was spent in light physical activity. These differences were significant in the sedentary $(p=0.041)$ and light $(p=0.011)$ categories. Only a small percentage of time was spent doing activities that contributed to high-intensity physical activity on both the weekday and the weekend day.

Table 4 describes the TEE and physical activity levels of the group during the morning (08:00-14:00) and the afternoon (14:00-20:00) on a weekday.

A significant difference ( $p=0.0035)$ was found between the TEE of the afternoon $(645.96 \mathrm{kcal})$ and the morning $(536.03$

TABLE 1: Descriptive statistics of participants (age, number and percentage).

\begin{tabular}{|c|c|c|c|c|c|c|c|}
\hline \multirow[t]{2}{*}{ Group } & \multirow[t]{2}{*}{$n$} & \multicolumn{2}{|c|}{ Age } & \multicolumn{2}{|c|}{ Overweight } & \multicolumn{2}{|c|}{ Obese } \\
\hline & & $M$ & $\sigma . \delta$. & $n$ & $\%$ & $n$ & $\%$ \\
\hline Boys & 7 & 11.36 & 1.10 & 4 & 57.14 & 3 & 42.86 \\
\hline White & 4 & 11.25 & 1.55 & 2 & 50.00 & 2 & 50.00 \\
\hline Black & 3 & 11.50 & 0.00 & 2 & 66.67 & 1 & 33.34 \\
\hline Girls & 17 & 10.94 & 0.85 & 5 & 29.41 & 12 & 70.59 \\
\hline White & 10 & 10.70 & 0.89 & 5 & 50.00 & 5 & 50.00 \\
\hline Black & 7 & 11.29 & 0.70 & 0 & 0.00 & 7 & 100.0 \\
\hline Group Total & 24 & 11.06 & 0.92 & 9 & 37.50 & 15 & 62.50 \\
\hline
\end{tabular}

$n$, number of subjects; $M$, mean; s.d., standard deviation; $\%$, percentage. 
TABLE 2: Body composition characteristics of 9 year-old - 12-year-old overweight and obese participants.

\begin{tabular}{|c|c|c|c|c|c|c|c|}
\hline \multirow[t]{2}{*}{ Group } & \multirow[t]{2}{*}{$n$} & \multicolumn{2}{|c|}{ Stature $(\mathrm{m})$} & \multicolumn{2}{|c|}{ Mass (kg) } & \multicolumn{2}{|c|}{ BMI } \\
\hline & & $M$ & $\sigma . \delta$. & $M$ & $\sigma . \delta$. & $M$ & $\sigma . \delta$. \\
\hline Boys & 7 & 1.52 & 0.11 & 60.34 & 15.73 & 26.03 & 3.76 \\
\hline White & 4 & 1.55 & 0.15 & 62.71 & 11.67 & 25.86 & 1.70 \\
\hline Black & 3 & 1.48 & 0.09 & 57.18 & 22.62 & 26.27 & 6.16 \\
\hline Overweight & 4 & 1.50 & 0.09 & 52.43 & 9.81 & 23.68 & 1.44 \\
\hline Obese & 3 & 1.55 & 0.15 & 70.9 & 17.47 & 29.17 & 3.67 \\
\hline Girls & 17 & 1.51 & 0.08 & 63.95 & 12.07 & 28.07 & 4.15 \\
\hline White & 10 & 1.51 & 0.08 & 60.88 & 13.56 & 26.58 & 4.34 \\
\hline Black & 7 & 1.50 & 0.09 & 68.34 & 8.61 & 30.21 & 2.92 \\
\hline Overweight & 5 & 1.49 & 0.09 & 52.24 & 7.41 & 23.37 & 1.29 \\
\hline Obese & 12 & 1.51 & 0.08 & 68.83 & 10.18 & 30.04 & 3.17 \\
\hline Group Total & 24 & 1.51 & 0.09 & 62.9 & 62.9 & 27.48 & 4.06 \\
\hline
\end{tabular}

$n$, number of subjects; $M$, mean; s.d., standard deviation.

TABLE 3: Total energy expenditure and amount of time spent by participants doing physical activity on a weekday and a weekend day.

\begin{tabular}{lcccccccccc}
\hline Variable & \multicolumn{2}{c}{ Weekday } & & \multicolumn{2}{c}{ Weekend day } & & $d f$ & $\boldsymbol{t}$ & $\boldsymbol{p}$ \\
\cline { 2 - 3 } & $\boldsymbol{M}$ & $\sigma . \delta$. & & $\boldsymbol{M}$ & $\sigma . \delta$. & & & \\
\hline TEE (kcal) & 1181.99 & 217.8 & & 1262.14 & 266.90 & 46 & -1.14 & 0.260 \\
Time (\%) (sed) & 47.47 & 15.43 & & 36.75 & 19.63 & 46 & 2.10 & $0.041^{*}$ \\
Time (\%) (light) & 42.90 & 12.15 & & 54.09 & 16.84 & 46 & -2.64 & $0.011^{*}$ \\
Time (\%) (mod) & 9.29 & 4.87 & & 8.79 & 6.91 & 46 & 0.29 & 0.770 \\
Time (\%) (high) & 0.35 & 0.89 & & 0.38 & 0.64 & 46 & -0.13 & 0.900 \\
Time (\%) (MHPA) & 9.64 & 5.48 & & 9.16 & 6.92 & 46 & 0.26 & 0.794 \\
\hline
\end{tabular}

TEE, total energy expenditure; sed, sedentary; mode, moderate; MHPA, moderate to high physical activity levels; $M$, mean; s.d., standard deviation; $d f$, degrees of freedom; $t, t$-value; $p$, significance; ${ }^{*}, p$-value $<0.05$

TABLE 4: Total energy expenditure and time spent by participants doing physical activity during a weekday morning and afternoon

\begin{tabular}{|c|c|c|c|c|c|c|c|}
\hline \multirow[t]{2}{*}{ Variable } & \multicolumn{2}{|c|}{ Weekday } & \multicolumn{2}{|c|}{ Weekend day } & \multirow[t]{2}{*}{$d f$} & \multirow[t]{2}{*}{$t$} & \multirow[t]{2}{*}{$p$} \\
\hline & $M$ & $\sigma . \delta$. & $M$ & $\sigma . \delta$. & & & \\
\hline TEE (kcal) & 536.03 & 107.31 & 645.96 & 138 & 46 & -3.08 & $0.004^{*}$ \\
\hline Time (\%) (sed) & 58.61 & 15.44 & 36.26 & 20.85 & 46 & 4.22 & $0.000 *$ \\
\hline Time (\%) (light) & 34.95 & 14.56 & 51.73 & 15.81 & 46 & -3.82 & $0.000 *$ \\
\hline Time (\%) (mod) & 7.21 & 2.76 & 11.38 & 9.13 & 46 & -2.14 & $0.038^{*}$ \\
\hline Time (\%) (high) & 0.06 & 0.16 & 0.64 & 1.75 & 46 & -1.62 & 0.110 \\
\hline Time (\%) (MHPA) & 7.27 & 2.85 & 12.01 & 10.25 & 46 & -2.19 & $0.034 *$ \\
\hline
\end{tabular}

TEE, total energy expenditure; sed, sedentary; mode, moderate; MHPA, moderate to high physical activity levels; $M$, mean; s.d., standard deviation; $d f$, degrees of freedom; $t, t$-value $p$, significance; ${ }^{*}, p$-value $<0.05$.

kcal). Significant differences were also evident between the morning and afternoon with regard to the sedentary $(p=$ $0.000)$, light $(p=0.000)$ and moderate levels $(p=0.038)$ of physical activity and TEE. More time was spent at the sedentary physical activity level during the morning (58.61\%) than during the afternoon, where more time was spent doing light physical activity (51.73\%). Only little time was spent doing activities that contributed to high physical intensity levels in both the morning and the afternoons.

Table 5 provides the analysis of the amount of time spent at the various physical activity levels for overweight and obese boys and girls respectively.

The overweight group spent more time at the moderate physical activity level on the weekday (boys $=79$ min.; girls $=101 \mathrm{~min}$ respectively) as well as on the weekend day (boys = 94 min.; girls $=64$ min.) than the obese group (on the weekday: boys $=44 \mathrm{~min}$., girls $=55 \mathrm{~min}$; on the weekend day: boys $=37 \mathrm{~min}$., girls $=55 \mathrm{~min}$.). Both the overweight boys and girls spent more time at the high-intensity physical activity level on the weekday than the obese boys and girls. The obese boys spent more time at the high-intensity physical activity level on the weekend day than the overweight boys and, in contrast, the obese girls spent less time at the highintensity physical activity levels on the weekend day than the overweight girls. Obese boys and girls were also more sedentary than the overweight boys and girls. These various activity intensities led to differences in the TEE.

\section{Ethical considerations}

Ethical approval of the research protocol was obtained from the Ethics Committee of the North-West University (no. 07M07). Permission to conduct the study was granted by the Department of Education of the North West Province and the headmasters of the identified schools. Parental consent and child assent were also obtained prior to the study, whilst a medical doctor had to declare the participants medically fit for participation in the study.

\section{Validity and reliability}

The ACTICAL ${ }^{\mathrm{TM}}$ monitor has been well validated in children (Pate, O'Neill \& Mitchell 2010:508). The strong correlations between activity counts, average energy expenditure and heart rate demonstrate that the ACTICAL ${ }^{\mathrm{TM}}$ monitors strongly reflect energy expenditure during activity. The validation of the monitors against average energy expenditure and their calibration for sedentary, light, moderate and vigorous levels of physical activity certify these monitors as valid, useful devices for the assessment of physical activity in children (Puyau et al. 2002:150).

\section{Discussion}

The results indicate that both overweight boys and overweight girls (when each gender was analysed separately), reached the prescribed goal of 60 minutes at the moderate physical activity level (PCPFS 2008) on both the weekday and the weekend day. This was, however, not the case for the obese boys and girls. Studies indicate that obese children often lack the motor skills and self-confidence to participate in activities and experience bodily discomfort (pain in their feet and inner-leg rash caused by scouring and sweating) whilst doing activities, resulting in their withdrawing from physical activity (Dowling, Steele \& Baur 2001:845; Page et al. 2005:510; Butte et al. 2007:1260). A significant difference was also evident between the TEE of the obese and the overweight girls, with the obese girls having spent more energy than the overweight girls. The higher TEE for the obese group may have been influenced by their diet, which is part of TEE (Rowland 1990). Spending less than 60 minutes at the moderate physical activity level is therefore not enough for the obese children to derive health benefits from their activity (PCPFS 2008). 
TABLE 5: Summary of TEE and time spent by participants in the various physical activity categories.

\begin{tabular}{|c|c|c|c|c|c|c|c|c|c|}
\hline \multirow[t]{2}{*}{ Variable } & \multirow{2}{*}{$\begin{array}{l}\text { Physical activity } \\
\text { levels }\end{array}$} & \multicolumn{2}{|c|}{ Overweight boys } & \multicolumn{2}{|c|}{ Obese boys } & \multicolumn{2}{|c|}{ Overweight girls } & \multicolumn{2}{|c|}{ Obese girls } \\
\hline & & $M$ & $\sigma . \delta$ & $M$ & $\sigma . \delta$ & $M$ & $\sigma . \delta$ & $M$ & $\sigma . \delta$ \\
\hline \multicolumn{10}{|l|}{ Weekday } \\
\hline TEE (kcal) & - & 1057.80 & 229.07 & 1238.71 & 258.35 & 1085.97 & 292.06 & 1249.22 & 161.60 \\
\hline \multirow[t]{5}{*}{ Time (min.) } & sed & 310.25 & 73.24 & 407.67 & 49.8 & 216.80 & 151.83 & 361.50 & 92.09 \\
\hline & light & 329.50 & 89.48 & 268.00 & 43.00 & 391.20 & 105.67 & 302.92 & 77.50 \\
\hline & $\bmod$ & 79.00 & 44.59 & 44.00 & 7.21 & 101.40 & 45.57 & 55.58 & 25.99 \\
\hline & high & 1.25 & 2.50 & 0.33 & 0.58 & 10.60 & 11.22 & 0.00 & 0.00 \\
\hline & MHPA & 80.25 & 47.09 & 44.33 & 7.79 & 112.00 & 56.79 & 55.58 & 25.99 \\
\hline \multicolumn{10}{|c|}{ Weekend day } \\
\hline TEE (kcal) & - & 1110.96 & 167.61 & 1347.17 & 325.76 & 1051.44 & 278.21 & 1379.07 & 220.60 \\
\hline \multirow[t]{4}{*}{ Time (min.) } & sed & 279.75 & 111.19 & 349.33 & 49.89 & 308.40 & 221.86 & 221.50 & 108.23 \\
\hline & light & 344.50 & 124.87 & 323.33 & 33.17 & 344.20 & 179.31 & 442.33 & 84.69 \\
\hline & $\bmod$ & 94.75 & 86.83 & 37.00 & 34.70 & 64.20 & 41.69 & 55.42 & 35.96 \\
\hline & high & 1.00 & 1.41 & 10.33 & 9.61 & 3.20 & 3.42 & 0.75 & 1.14 \\
\hline
\end{tabular}

TEE, total energy expenditure; sed, sedentary; mod, moderate; MHPA, moderate to high intensity physical activity levels; $M$, mean; s.d., standard deviation.

The lower physical activity levels seen in the group during the weekdays can be ascribed to the fewer hours spent on physical education in the school curriculum. Only 33\% of the total time allocated for the learning areas in Life Orientation in Grade 4-6 is for physical development and movement (Rajput \& Van Deventer 2010:142). It often happens that schools do not use this time for physical activities because they do not have qualified teachers, or the allocated time is used for learning areas which they consider more important. Children also spend more time indoors after school owing to unsafe environments (Hills, King \& Armstrong 2007) and on sedentary activities like watching television and playing computer games (Medical Research Council 2002). Doing homework in the afternoons is also a sedentary activity.

No significant differences with regard to TEE and time spent at various physical activity levels were found for the weekday and the weekend day, although a higher mean TEE was indicated during the weekend day. This is, however, contradictory to the findings by Aires et al. (2007:871) on 8-16-year-old overweight and obese children, which showed that these children were more active on the weekday than on the weekend day. Aires et al. (2007) showed that overweight and obese children spent $2.7 \%$ of the time in the MHPA levels during the weekend day, which is less than found in our study $(9.17 \%)$. A possible reason for the slightly higher activity levels found on weekends in our group is that some overweight (not obese) participants were involved in school sports (athletics) during the weekend. The activity diaries further indicated that some of the overweight participants played outside more (which is often more vigorous activity) during the weekend days. It might be that parents are at home more often during weekends and can provide supervision for outside play than during the weekdays. The obese children prefer sedentary activities, like watching TV and playing computer games. It therefore seems as if young obese children already experience the burden of their heavy bodies and the discomfort associated with movement at this early age, which influence the intensity of their activity choices.
A comparison of TEE and morning and afternoon physical activity levels of the group showed significant differences, with the TEE being higher in the afternoon than in the morning. Differences between the time spent at the different activity levels (sedentary, light and moderate) during the morning and afternoon session were also found, with significantly more time spent at the light and moderate physical activity levels in the afternoon, while less was spent at the sedentary physical activity level. Research with children of normal weight (Fairclough, Butcher \& Stratton 2007:421) as well as obese 3-year-olds - 5-yearolds (Vasquez et al. 2006:1115) showed that these children were more active in the morning than in the afternoon. The research by Fairclough et al. (2007) included physical education (PE) periods during the morning hours, and these PE periods were the most active time of the morning. The results of Vasquez et al. (2006:1117) are also to be expected, as toddlers have more free time for play during school hours than children who attend formal schooling. In our study the children did not have a formal PE period. These differences highlight the importance of physical activity sessions during school time. The amount of time spent on activities of MHPA intensity was also higher during the afternoon, although not significantly so $(7.27 \%$ in the morning vs $12.12 \%$ in the afternoon). A possible explanation for this could be that children are more sedentary during the morning because they are at school, and more active in the afternoon because they can take part in extramural activities. It would thus appear that school hours are restrictive to the TEE of already overweight or obese children.

\section{Limitations of the study}

Some limitations should be considered when interpreting the findings of this study. Although many children were identified and classified into the overweight and obese categories during the baseline part of this study, few of these children's parents consented to their participation in the current study. The research group was therefore small and the boy:girl ratio also resulted in uneven numbers, which complicated generalisation of the results. The results of the study must therefore be judged in view of a limited sample 
size and absence of a control group. Another limitation was that only physical activity was considered as part of the energy balance, while this phenomenon is influenced by a complex interplay of factors such as diet and basal metabolism. Even if children are physically active and meet the minimum requirements for health purposes, a diet high in fat, sugar and carbohydrates can contribute to an unhealthy energy balance in the long run. Regardless of these shortcomings, the study provides valuable information concerning the physical activity and energy expenditure of overweight and obese children, which can be used to plan strategies to increase the physical activity levels of these children.

\section{Recommendations}

Future studies are encouraged in order to form a better understanding of the energy balance and the physical activity choices of overweight children. Improved understanding will lead to strategies to improve the physical activity of overweight and, especially, obese children.

\section{Conclusion}

The results show that the obese boys and girls did not spend the recommended 60 minutes of moderate physical activity per day, whereas the overweight boys and girls did meet these requirements. The results indicate that 60 minutes of moderate physical activity may, however, not be enough to combat overweight, and especially obesity, among children as young as 9 years. The physical activity levels and TEE of 9-year-old - 12-year-old overweight or obese children were found to be similar during the weekday and the weekend day, with a tendency towards less physical activity on the weekday. It was, however, significantly higher during the weekday afternoon. These findings have implications for intervention programmes that include overweight and obese children, as it would appear that intervention programmes will have to include activities of higher intensities for longer than 60 minutes to combat obesity. Overweight and obese children will also have to be furnished with knowledge and skills to make more active choices during weekday mornings while at school, and even during weekends.

\section{References}

Aires, L., Santos, R., Silva, P., Santos, P., Oliveira, J., Ribeiro, J.C. et al., 2007, 'Daily differences in patterns of physical activity among overweight/obese children engaged in a physical activity program', American Journal of Human Biology 19 871-877. doi:10.1002/ajhb.20658, PMid:17724744

Al-Nakeeb, Y., Duncan, M.J., Lyons, M. \& Woodfield, L., 2007, 'Body fatness and physical activity levels of young children', Annals of Human Biology 34(1), 1-12. doi:10.1080/03014460601079886, PMid:17536750

Armstrong, M.E.G., Lambert, M.I., Sharwood, K.A. \& Lambert, E.V., 2006, 'Obesity and overweight in South African primary school children - The Health of the Nation study', South African Medical Journal 11(2), 52-63.

Butte, N.F., Puyay, M.R., Adolph, A.L., Vohra, F.A. \& Zakeri, I., 2007, 'Physical activity in nonoverweight and overweight Hispanic children and adolescents', Medicine \& Science in Sports and Exercise 39(8), 1257-1266. doi:10.1249/ mss.0b013e3180621fb6

Cole, T.J., Bellizzi, M.C., Flegal, K.M. \& Dietz, W.H., 2000, 'Establishing a standard definition for child overweight and obesity worldwide:international survey', British Medical Journal 320, 1240-1243.
Department Of Health And Human Services: the President's Coucil On Physical Fitness And Sport, 2008, Physical activity facts, viewed 21 August 2008, from http://www. fitness.gov/resources_factsheet.htm

Dowling, A.M., Steele, J.R. \& Baur, L.A., 2001, 'Does obesity influence foot structure and plantar pressure patterns in prepubescent children?', International Journal of Obesity 25, 845-852. doi:10.1038/sj.ijo.0801598, PMid:17275899

Duncan, M.J., Al-Nakeeb, Y., Woodfield, L. \& Lyons, M., 2007, 'Pedometer determined physical activity levels in primary school children from central England', Preventive Medicine 44(5), 416-420. doi:10.1016/j.ypmed.2006.11.019

Fairclough, S.J., Butcher, Z.H. \& Stratton, G., 2007, 'Whole-day and segmented-day physical activity variability of Northwest England school children', Preventive Medicine 44(5), 421-425. doi:10.1016/j.ypmed.2007.01.002

Goldfield, G.S., Mallory, R., Prud'homme, D. \& Adamo, K.B., 2008, 'Gender differences in response to a physical activity intervention in overweight and obese children', Journal of Physical Activity and Health 5, 592-606.

Grund, A., Volbrecht, H., Frandsen, W., Krause, H., Siewer, M., Rieckert, H. et al., 2000 , 'No effect of gender on different components of daily energy expenditure in free living prepubertal children', International Journal of Obesity 24, 299-305. doi:10.1038/sj.ijo.0801127, PMid:17503878

Hills, A.P., King, N.A. \& Armstrong, T.P., 2007, 'The contribution of physical activity and sedentary behaviours to the growth and development of children and adolescents', Sports Medicine 37(6), 533-545. doi:10.2165/00007256-200737060-00006

Marfell-Jones, M., Olds, T., Stewart, A. \& Carter, J.E.L., 2006, International Standards for Anthropometric Assessment, ISAK, Potchefstroom.

Medical Research Council, 2002, Umthente uhlaha usamila: The 1st South African National Youth Risk Behaviour Survey, viewed 11 May 2010, from http://www. $\mathrm{mrc}$.ac.za/healtpromotion/reports.htm

Mini Mitter Company Inc., 2003, ACTICAL TM Physical activity monitoring system. Instruction manual. Software version 2.0, Mini Mitter Company Inc, Bend, Oregon.

Ogden, C.L., Carroll, M.D., Curtin, L.R., McDowell, M.A., Tabak, C.J. \& Flegal, K.M., 2006, 'Prevalence of overweight and obesity in the United States, 1999-2004', The Journal of the American Medical Association 295(3), 1549-1555.

Page, A., Cooper, A.R., Stamatakis, E., Foster, L.J., Crowne, E.C., Sabin, M. et al., 2005 'Physical activity patterns in nonobese and obese children assessed using minuteby-minute accelerometry', International Journal of Obesity 29, 1070-1076. doi:10.1038/sj.ijo.0802993, PMid:11886937

Pate, R.R., O'Neill, J.R. \& Mitchell, J., 2010, 'Measurement of physical activity in preschool children', Medicine and Science in Sports \& Exercise 42(3), 508-512. doi:10.1249/MSS.0b013e3181cea116

PCPFS. See Department Of Health And Human Services.

Puyau, M.R., Adolph, A.L., Vohra, F.A. \& Butte, N.F., 2002, 'Validation and calibration of physical activity monitors in children', Obesity Research 10, 150-157. doi:10.1038/ oby.2002.24

Rajput, D.I. \& Van Deventer, K., 2010, 'An epoch of controversy within physical education and sport in post-apartheid South Africa: A review', African Journal for Physical, Health Education, Recreation and Dance 16(1), 140-158.

Reilly, J.J. \& Dorosty, A.R., 1999, 'Epidemic of obesity in UK children', Lancet 354 , 1874-1875. doi:10.1016/S0140-6736(99)04555-9, PMid:18162187

Rowland, T.W., 1990, Exercise and children's health, Human Kinetics, Atlanta.

Rowlands, A.C., Pilgrim, E.L. \& Eston, R.G., 2007, 'Patterns of habitual activity across weekdays and weekend days in 9-11-year-old children', Preventive Medicine 46(4), 317-332. doi:10.1016/j.ypmed.2007.11.004

Statsoft, 2009, Statistica for Windows. Release 8.0: General conventions and statistics, Statsoft, Tilsa, Okla.

Steinbeck, K., 2001, 'Obesity in children: The importance of physical activity', Australian Journal of Nutrition and Dietetics, 58(1), S28-S32.

Trost, S.G., Pate, R.R., Freedom, P.S., Sallis, J.F. \& Taylor, W.C., 2000, 'Using objective physical activity measures with youth: How many days of monitoring are needed?', Medicine \& Science in Sports \& Exercise 32, 426-431. doi:10.1097/00005768200002000-00025

Trost, S.G., Sirard, J.R., Dowda, M., Pfeiffer, K.A. \& Pate, R.R., 2003, 'Physical activity in overweight and nonoverweight preschool children', International Journal of Obesity and Related Metabolic Disorders 27(7), 834-839.

Trost, S.G., Mclver, K. \& Pate, R.R., 2005, 'Conducting accelerometer-based activity assessments in field-based research', Medicine \& Science in Sports \& Exercise 37 S531-S543. doi:10.1249/01.mss.0000185657.86065.98, PMid:17902211

Vasquez, F., Salazar, G., Andrade, M., Vasquez, L. \& Diaz, E., 2006, 'Energy balance and physical activity in obese children attending day-care centres', European Journal of Clinical Nutrition 60, 1115-1121. doi:10.1038/sj.ejcn.1602426, PMid:3493862, PMCid:2490974

Wang, Y. \& Lobstein, T., 2006, 'Worldwide trends in childhood overweight and obesity', International Journal of Pediatric Obesity 1, 11-25. doi:10.1080/17477160600586747, PMid:10797032, PMCid:27365

World Health Organization, 1986, 'Use and interpretation of anthropometric indicators of nutritional status', Bulletin of the World Health Organization 64, 929-941.

World Health Organization, 2009, Obesity statistics, viewed 01 April 2009, from http:// www.who.int/mediacentre/factsheets/fs311/en 